\title{
Toward improved postpartum cyclicity of primiparous dairy cows: Effects of genetic merit for production traits under contrasting feeding systems
}

\author{
N. Bedere,${ }^{*} \dagger$ L. Delaby, ${ }^{*} \dagger$ V. Ducrocq, $\neq$ S. Leurent-Colette, $\S$ and C. Disenhaus ${ }^{*} \dagger^{1}$ \\ *INRA UMR 1348 PEGASE, F 35590 Saint-Gilles, France \\ †Agrocampus-Ouest UMR 1348 PEGASE, F 35000 Rennes, France \\ †INRA UMR 1313 GABI, F 78352 Jouy-en-Josas, France \\ §INRA UE 326 Domaine Expérimental du Pin-au-Haras, F 61310 Exmes, France
}

\begin{abstract}
Milk genetic merit is known to affect commencement of luteal activity (C-LA) in dairy cows. This effect is considered to be due to energy exported in milk production. The present study aimed to identify and quantify the effects of genetic characteristics [breed and estimated breeding value (EBV) for milk yield and fat and protein contents] and feeding system on C-LA of primiparous cows. From 2006 to 2013, an experiment was conducted on 97 primiparous dairy (Holstein) and 97 primiparous dual-purpose (Normande) cows. Within breed, cows were classified into 2 groups: cows with high EBV for milk yield were included in a "milk group" and those with high EBV for fat and protein contents were included in a "content group." Within breed, exported energy in milk and body weight (BW) loss were similar for both genetic groups. Two grazing-based strategies were used, a high feeding system (maize silage in winter and grazing plus concentrate) and a low feeding system (grass silage in winter and grazing with no concentrate). Interval from calving to C-LA was studied performing survival analyses. Milk progesterone profile, milk yield, and body condition were analyzed using $\chi^{2}$-test and analysis of covariance. Holstein cows produced more milk $(+1,810 \mathrm{~kg}$ in the high feeding system and $+1,120$ $\mathrm{kg}$ in the low feeding system) and lost more BW from wk 1 to 14 of lactation $(-1.4 \mathrm{~kg} / \mathrm{wk})$ than Normande cows, whereas Normande cows had earlier C-LA than Holstein cows. Within breed, cows in the content group had earlier C-LA (associated hazard ratio $=2.0$ ) than cows in the milk group. Body weight at calving and loss from wk 1 to 14 of lactation tended to be associated with later C-LA. Cows in the high feeding system produced more milk $(+2,040 \mathrm{~kg}$ for the Holstein cows and $+1,350 \mathrm{~kg}$ for Normande cows) and lost less BW from wk 1 to 14 of lactation $(+3.8 \mathrm{~kg} /$ wk $)$ than cows
\end{abstract}

Received May 21, 2015.

Accepted September 8, 2015.

${ }^{1}$ Corresponding author: catherine.disenhaus@agrocampus-ouest.fr in the low feeding system. No effect of feeding system or milk yield was observed on C-LA. Prolonged luteal phases were frequent (18\% of cows) and were not associated with either breed or genetic group. Ovarian cycles were longer for Holstein than for Normande cows $(+1.7 \mathrm{~d})$ because of a longer luteal phase and a longer interluteal interval. Results of the study could be useful to establish strategies to manage declining reproductive performances at genetic and environmental levels. This study showed that cows with a genetic predisposition to export milk energy through fat and protein contents had earlier C-LA than predisposed to export milk energy through yield.

Key words: dairy cow, cyclicity, genetic merit, primiparous

\section{INTRODUCTION}

In dairy cows, milk production and reproduction are concomitant. Reproductive performance has been declining while milk production has been increasing (Friggens et al., 2010). Failure in reproduction causes economic losses, disturbs the working plan (e.g. breeding calendar), and represents a mental load (i.e., the stress of missing estruses) for farmers.

In spring-calving pasture-based systems, cows are under the constraint of a breeding period because feed demand needs to be adjusted to grass supply. The ability of cows to resume normal ovarian cyclicity on time is required and it affects the subsequent steps of the reproductive process (Darwash et al., 1997; Gautam et al., 2010). Abnormal ovarian activity is common in the current dairy cow population: only $60 \%$ of Holstein cows have normal cyclicity, and the major abnormal cyclicity pattern is delayed commencement of luteal activity (C-LA; Petersson et al., 2006; Windig et al., 2008; Cutullic et al., 2011). In most countries, dairy cattle include a large proportion of primiparous cows because the replacement rate is high (from 20 to $40 \%$; Le Cozler et al., 2008). Lactation number is one of the factors influencing milk production and reproduction. Primiparous cows have lower milk yield and experience 
delayed C-LA compared with multiparous cows (Opsomer et al., 1998; Taylor et al., 2003). When cows are still growing, they have different metabolic status, endocrine responses, and partitioning of nutrients toward organs during their first lactation than during subsequent ones (Taylor et al., 2003; Coffey et al., 2006).

Thirteen to $30 \%$ of the observed variance of C-LA is due to genetics and C-LA is unfavorably genetically correlated with milk yield (Veerkamp et al., 2000; Royal et al., 2002b; Petersson et al., 2007). For instance, breeds selected for milk yield have later C-LA than dual-purpose (milk and meat production) breeds. Holstein cows show more abnormal cyclicity profiles than others, especially delayed first ovulation (Petersson et al., 2006; Cutullic et al., 2011; Piccand et al., 2013). However, the deleterious effect of high genetic merit for milk yield on cyclicity is not always clear (Horan et al., 2004; Pollott and Coffey, 2008; Windig et al., 2008).

A key environmental factor affecting dairy cow milk production and reproduction is nutrition (Canfield et al., 1990; Burke and Roche, 2007; Chagas et al., 2008). In early lactation, dairy cows require a large amount of nutrients to ensure milk production. Their intake capacity is too low to fulfill these requirements and they experience a negative energy or protein balance. To cope with this deficit, cows mobilize body reserves. Low body reserves at calving or high mobilization at the beginning of lactation are risk factors for later C-LA. In addition, cows that are too fat at calving experience more abnormal cyclicity patterns (Cutullic et al., 2012). Even though body condition and body condition loss influence C-LA, milk yield per se does not. However, the occurrence of prolonged luteal phase (PLP) may be related to milk yield (Royal et al., 2002b; Kafi et al., 2012).

The present study aimed to identify and quantify the effect of breed, genetic merit for milk yield, and feeding system on postpartum cyclicity of primiparous dairy cows. Our hypotheses were that (1) cows with genetic characteristics (breed and genetic merit) in favor of milk yield have deteriorated cyclicity; (2) feeding systems affect milk production and body condition (reserves) and mobilization, which are related to cyclicity. Results of the study could be useful to establish strategies to cope with declining reproductive performances at genetic and environmental levels.

\section{MATERIALS AND METHODS}

\section{Animals and Experimental Design}

Starting in 2006, an experiment was conducted at the dairy research farm of Le Pin-au-Haras (Normandy,
France). At the beginning of the experiment, animals were equally distributed among genetic characteristics ( 2 breeds, 2 genetic groups) and feeding strategies (2 feeding systems).

A total of 97 primiparous Normande (dual-purpose cows) and 97 primiparous Holstein (dairy cows) were involved in the trial. Within breed, cows were classified into 2 groups according to their EBV for milk yield and fat and protein contents as 2 groups capable of producing the same solid milk quantity in a different manner. The EBV for each trait was evaluated by using a BLUP animal model that included the sire and grandsire's genetic evaluation, the dam's performance over 3 lactations, the classical fixed environmental effects (year, lactation number, calving age, calving month, length of drying off period, and permanent environmental effect) and the feeding system (H. Larroque, INRA UMR 1388 GenPhySE, Toulouse, France; personal communication). For Holstein cows, EBV for milk yield varied between $+1,726$ and $+3,966 \mathrm{~kg}$, EBV for fat content varied between -6.9 and $+3.5 \mathrm{~g} /$ $\mathrm{kg}$, and EBV for protein content varied between -0.8 and $+3.8 \mathrm{~g} / \mathrm{kg}$. For Normande cows, EBV for milk yield varied between +948 and $+2,815 \mathrm{~kg}$, EBV for fat content varied between -4.2 and $+5.7 \mathrm{~g} / \mathrm{kg}$, and EBV for protein content varied between -0.8 and $+4.7 \mathrm{~g} /$ $\mathrm{kg}$. Within breeds and experimental years, nulliparous cows with higher EBV for milk yield than the average and lower EBV for fat and protein contents than the average were classified in the milk group (MG). Nulliparous cows with lower EBV for milk yield than the average and higher EBV for fat and protein contents than the average were classified in the content group (CG). The other nulliparous animals (high EBV for milk yield and high EBV for fat and protein contents or low EBV for milk yield and low EBV for fat and protein contents) did not enter the experiment. Fiftytwo Holstein and 44 Normande were classified in MG and 45 Holstein and 53 Normandewere classified in CG. Table 1 describes the diet fed to cows in each feeding system. In both breeds, 44 cows were managed under a "high" feeding system that enabled high milk yield while limiting body condition loss; and 53 cows were managed under a "low" feeding system that limited milk yield while inducing high body condition loss. Cows remained in their feeding system until they were culled due to lack of pregnancy, severe health problem, or accidental death. Among the 231 primiparous cows that participated in this study, 25 heifers failed to conceive on time to fit the compact calving system, 7 could not be milked, and 5 had severe health problems. Finally, 194 primiparous cows were included in the analyses of the present study. 
Table 1. Composition of the diets of the high and low feeding systems during stock, pasture, and dry periods

\begin{tabular}{|c|c|c|}
\hline \multirow[b]{2}{*}{ Feedstuff } & \multicolumn{2}{|c|}{ Feeding system } \\
\hline & High & Low \\
\hline \multicolumn{3}{|l|}{ Stock diet } \\
\hline Maize silage $(\%$ of $\mathrm{DM})$ & 55 & - \\
\hline Dehydrated alfalfa pellets ( $\%$ of DM) & 15 & - \\
\hline Grass silage $(\%$ of $\mathrm{DM})$ & - & 50 \\
\hline Haylage $(\%$ of DM) & - & 48 \\
\hline $\begin{array}{l}\text { Concentrates }+ \text { minerals and vitamins } \\
(\% \text { of DM })\end{array}$ & 30 & - \\
\hline Minerals and vitamins (\% of DM) & - & 2 \\
\hline \multicolumn{3}{|l|}{ Pasture feeding } \\
\hline Rotational grazing (ha/cow) & 0.35 & 0.60 \\
\hline Concentrates $(\mathrm{kg})$ & 4.0 & - \\
\hline Minerals and vitamins (kg) & 0.25 & 0.50 \\
\hline \multicolumn{3}{|l|}{ Dry period } \\
\hline Grass silage (\% of DM) & 100 & 100 \\
\hline
\end{tabular}

\section{Reproductive Management}

The herd was managed under a 3-mo compact calving system (January to March). After calving, uterine involution was checked by rectal palpation 25 to $30 \mathrm{~d}$ postpartum. When involution was achieved, AI were performed on spontaneous estruses, if expressed at least $40 \mathrm{~d}$ postpartum and during the breeding period (April to June). If cows were expressing new estrus in the $35 \mathrm{~d}$ following a service, AI was performed again. Otherwise, ultrasonography was conducted to diagnose pregnancy status. If the first diagnosis was positive, a second diagnosis was performed $60 \mathrm{~d}$ after last service.

Health events were recorded throughout the lactation with special attention to reproductive problems (calving difficulties, cesarean, retained placenta, metritis). For cesarean, retained placenta, or abnormal involution, cows were injected with a prostaglandin analog (cloprostenol, Estrumate, Schering-Plough, France). For severe metritis, intrauterine infusion of penicillin $\mathrm{G}$ and dihydrostreptomycin (Metrijet, Intervet, Beaucouzé, France) was also used to complete benefits from cloprostenol injection. Anestrus cows did not receive prostaglandin analog to resume ovarian activity.

\section{Sampling and Measurements}

Cows were milked twice daily at 0630 and $1600 \mathrm{~h}$. Individual milk yields were recorded by flow meters (Metatron, Westfalia, Germany). Three times a week, fat and protein contents were determined by infrared analyzer (MilkoScan, Foss Electric, Hillerød, Denmark), from individual a.m. and p.m. milk samples. From calving to either 2 wk after the service inducing pregnancy or to $5 \mathrm{wk}$ after the end of the breeding sea- son (i.e., July), morning milk samples were collected on Monday, Wednesday, and Friday, and stored at $-20^{\circ} \mathrm{C}$ for progesterone determination by commercial ELISA kits (Milk Progesterone ELISA, Ridgeway Science Ltd., Lydney, UK). The coefficients of variation between assays for ELISA on $5 \mathrm{ng} / \mathrm{mL}$ control samples ranged between 8 and 14\% among experimental years.

Body condition score ( $0-5$ scale with 0.25 increments) was evaluated monthly by the same 2 trained assessors, as described by Bazin et al. (1984). Body weight at calving was evaluated during the first $2 \mathrm{~d}$ of the first lactation week.

\section{Variables and Computation}

Estimation of Energy Exported in Milk. Energy exported in milk was estimated according to Faverdin et al. (2007):

$$
\begin{aligned}
& \text { Milk energy }(\mathrm{kJ})=7,115 \times \text { milk yield } \\
& \times\{0.44+[0.0055(\text { fat content }-40)] \\
& \quad+[0.0033(\text { protein content }-31)]\} .
\end{aligned}
$$

Determination of Luteal Activity. Two progesterone (P4) milk concentration thresholds were defined as in Petersson et al. (2006) adapted by Cutullic et al. (2011) to distinguish (1) the baseline level of progesterone in milk from the luteal phase level (threshold 1), and (2) a low luteal phase level from a high luteal phase level (threshold 2). Progesterone values were qualified as follows: negative (<threshold 1$)$, positive ( $>$ threshold 2), and intermediate. In short, increases of milk P4 concentrations were considered to be induced by corpus luteum activity if at least 2 consecutive values were not negative and at least 1 was positive. Decreases in milk $\mathrm{P} 4$ concentrations were considered to result from luteolysis of the corpus luteum when at least 1 value became negative. These definitions enabled us to identify and distinguish luteal phases from interluteal phases.

Qualification of Progesterone Profiles. For each luteal phase, physiological intervals were computed: C-LA, cycle length [interovulatory interval (IOI), luteal phase length (LUT), and interluteal interval (ILI); for details, see Cutullic et al., 2011]. Ovulation was considered to induce a PLP if the luteal phase lasted longer than $25 \mathrm{~d}$. Ovulation was considered to be delayed if ILI was longer than $12 \mathrm{~d}$. Based on these definitions, P4 profiles were classified as (1) normal, (2) PLP profile (if at least one PLP was observed), (3) delayed (if C-LA >60 d), (4) interrupted (if at least one ovulation of rank $>2$ was delayed), or (5) disordered 
(if luteal activity appeared irregular but could not be included in any abnormality class).

\section{Statistical Analyses}

Zootechnical Performance. Effects of experimental factors (breed, genetic group, feeding system, and calving age) on zootechnical performance were studied through analysis of covariance (ANCOVA) using the $l m$ procedure of the $\mathrm{R}$ statistical package ( $\mathrm{R}$ Core Team, 2014). Post hoc tests were performed through Tukey's pairwise comparison of the means (lsmeans procedure in R). The initial model included associated EBV when the dependent variables were total milk yield over the lactation, average daily milk yield, fat content, and protein content during the first $14 \mathrm{wk}$ in milk, total energy exported in milk over the lactation, and average daily energy exported in milk during the first $14 \mathrm{wk}$ in milk. Year of experiment, calving age group, feeding system, breed, genetic group, and first-order interactions between breed and other experimental factors were also included in the initial model. The final model was determined using a stepwise selection procedure.

Type of $\mathrm{P}_{4}$ Profile and Cycle Length. Chisquared analyses were performed to test the significance of the difference of the number of animals in each breed, feeding system, calving age, genetic group (global and within each breed), per type of $\mathrm{P} 4$ profile. Effects of experimental factors (breed, genetic group, feeding system, and calving age) on IOI, LUT, and ILI were studied by ANOVA ( $l m$ procedure in R) for the first cycles. For the second to the fourth cycles, similar analyses were performed with the addition of the random (genetic and nongenetic) effect of the cow, using mixed models (lmer procedure in $\mathrm{R}$ ).

$\boldsymbol{C}-\boldsymbol{L} \boldsymbol{A}$. Commencement of luteal activity was defined as the time between calving and C-LA in days. When no luteal phase was observed before the end of the breeding season (day $t$ of lactation), C-LA was set to $t$ and treated as censored (i.e., the true C-LA was only known to be larger than $t$ ). Time variables such as C-LA are classically studied using survival techniques modeling the hazard function. The hazard function $h(t)$ for C-LA is the limiting probability of starting luteal activity at time $t$ given it had not started yet just before $t$ (Kalbfleisch and Prentice, 2002). A proportional hazard model (PHM) was assumed: the hazard at $t$ was described as the product of a baseline hazard function $h_{0}(t)$ describing the overall C-LA and a positive term $\exp \left\{\mathbf{x}^{\prime} \beta\right\}$ describing the influence of explanatory variables on the hazard at time $t$ (Kalbfleisch and Prentice, 2002; Cox, 2007).
To test the validity of the PHM assumption, the raw (Kaplan-Meier) estimate of $S(t)$, the survival function for C-LA, was computed separately for different groups; that is, the 2 breeds (Kaplan and Meier, 1958). The PHM assumption is valid when a plot of the logarithm of $S(t)$ against the $\log (t)$ for different groups leads to parallel lines. From these plots, we concluded there was a need for stratification according to breeds (i.e., a distinct baseline hazard had to be assumed for each breed) and that the within-breed baseline hazard could be well approximated by a Weibull hazard function. The Weibull hazard function is a parametric description of $h_{0}(t)$ using only 2 parameters ( $\rho$ and $\lambda$ ), where $h_{0}(t)=\lambda \rho(\lambda t)^{\rho-1}$, with distinct Weibull parameters for each breed.

Among the explanatory variables, some are qualitative (e.g., genetic group), some are quantitative and remain constant over time (e.g., EBV), and others are quantitative and time-dependent (e.g., BW). The final stratified Weibull model was determined by stepwise selection:

$$
h(t ; \mathbf{x}, \mathbf{z})=h_{0, \text { breed }}(t) \exp \left\{\mathbf{x}^{\prime} \beta+\mathbf{z}^{\prime}(t) \varphi\right\},
$$

where $h_{0, \text { breed }}(t)$ is the baseline hazard function for each breed as described above; $\mathbf{x}$ is an incidence vector relating the hazard function to a set of time independent effects, $\beta$, including the year of experiment, the presence/absence of calving problems (caesarian, vagina displacement, infectious vaginitis, metritis of grade $3 / 3$, non-delivery), the genetic group, the EBV for milk yield and BW at calving; $\mathbf{z}$ is an incidence vector relating the hazard function to the time-dependent effect of changes in BW. Parameters were estimated by maximum likelihood.

Survival functions for a specific individual with given characteristics specified in the $\mathbf{x}$ and $\mathbf{z}$ vectors were predicted using the following expression:

$$
\hat{S}(t ; \mathbf{x}, \mathbf{z})=\int_{0}^{t} \hat{h}_{0, \text { breed }}(u) \exp \left\{\mathbf{x}^{\prime} \hat{\beta}+\mathbf{z}^{\prime}(u) \hat{\varphi}\right\},
$$

where $\hat{h}_{0, \text { breed }}, \hat{\beta}$, and $\hat{\varphi}$ are the estimated parameters. All survival analyses were performed using the Survival Kit statistical package (Mészáros et al., 2013).

\section{RESULTS}

During this experiment, 50 cows experienced calving problems; their production performance was similar to that of healthy cows. However, they had later CLA and 
the effect of calving problems was accounted for in the analyses.

\section{Production Performance}

Higher Milk Yield and Greater Body Condition Loss for Cows with High Genetic Merit for Milk Yield. Holstein cows produced more milk throughout their lactation $(+1,810 \mathrm{~kg}$ in the high feeding system and $+1,120 \mathrm{~kg}$ in the low feeding system, $P<0.001$; Table 2) than Normande cows. In both breeds, cows in MG produced more milk throughout their lactation than cows in CG $(+408 \mathrm{~kg}, P<0.05$, and $+350 \mathrm{~kg}, P$ $<0.1$, respectively, for Holstein and Normande cows). Holstein cows had similar fat content $(P=0.77)$ and lower protein content $(-2.5 \mathrm{~g} / \mathrm{kg} ; P<0.001)$ over the first 14 wk of lactation than Normande cows. Within breed, cows in MG had lower fat content $(-1.8 \mathrm{~g} / \mathrm{kg}, P$ $<0.01$, and $-2.6 \mathrm{~g} / \mathrm{kg}, P<0.001$, respectively, for Holstein and Normande cows) and lower protein content over the first 14 wk of lactation $(-1.1 \mathrm{~g} / \mathrm{kg}, P<0.01$ for both breeds). Holstein cows exported more energy in milk over the lactation than did Normande cows $(+4,430 \mathrm{MJ}$ in the high feeding system and $+2,790$ MJ in the low feeding system; $P<0.001$ ). Cows in MG exported similar amounts of energy as those in $\mathrm{CG}$ throughout lactation $(P=0.84)$.

Breed did not affect BCS at calving or BW at calving $(P=0.36$ and $P=0.91$, respectively). However, Holstein cows lost more body condition to nadir $(-0.8$, $P<0.001)$ and experienced greater BW loss over the first 14 wk of lactation $(-1.4 \mathrm{~kg} / \mathrm{wk}, P<0.01)$. Within breed, genetic group did not affect BCS at calving ( $P$ $=0.17)$. Holstein cows in MG were heavier at calving than cows in CG $(+32 \mathrm{~kg}, P<0.05)$, whereas for Normande cows, genetic group did not affect BW at calving $(P=0.99)$. For Holstein cows, genetic group did not affect BCS loss to nadir $(P=0.82)$ whereas for Normande, cows in MG tended to lose more BCS to nadir than cows in $\mathrm{CG}(-0.25, P<0.1)$. Within breed, genetic group did not affect BW loss over the first 14 wh of lactation $(P=0.40)$.

Higher Milk Yield and Lower Body Condition Loss for Cows in the High Feeding System. Cows in the high feeding system produced more milk than cows in the low feeding system $(+2,040 \mathrm{~kg}$ for the Holstein cows and $+1,350 \mathrm{~kg}$ for Normande cows, $P<$ 0.001). They also had higher protein content $(+3.5 \mathrm{~g} /$ $\mathrm{kg}, P<0.001)$ and tended to have higher fat content $(+0.6 \mathrm{~g} / \mathrm{kg}, P<0.1)$. Cows in the high feeding system exported more energy in milk throughout lactation than did cows in the low system $(+6,200 \mathrm{MJ}$ for the Holstein cows and $+4,560 \mathrm{MJ}$ for the Normande cows, $P<0.001)$. Feeding system did not affect BCS at calv- ing $(P=0.24)$. However, cows in the high system had greater $\mathrm{BW}$ at calving than cows in the low system (15 $\mathrm{kg}, P<0.05)$. Cows in the high system lost less BCS to nadir $(+0.58, P<0.001)$ and $\mathrm{BW}$ over the first 14 wk of lactation $(+3.8 \mathrm{~kg} /$ wk, $P<0.001)$ than cows in the low system.

\section{Cyclicity}

Later C-LA for Cows with High Genetic Merit for Milk Yield. Commencement of luteal activity ranged from 10 to 205 d postpartum, with a median of $30 \mathrm{~d}$. Two cows had censored C-LA. Breeds were treated as population strata and Figure 1 shows that Holstein cows had later C-LA than Normande cows. In both breeds, cows in CG were 2 times more likely to show C-LA than those in MG $(P<0.001$; Table 3$)$. In addition, within breed and genetic group, the higher the EBV for milk yield, the lower the chance (or, from a survival analysis point of view, the risk), to show C-LA $(P<0.05)$.

Later C-LA for Cows with Greater BW at Calving and $B W$ Changes. In all breeds and genetic groups, cows with greater $\mathrm{BW}$ at calving tended to have a higher risk to show C-LA than those with lesser BW at calving $(P<0.1$; Table 3$)$. In addition, greater BW losses tended to be associated with lower risk of showing C-LA $(P<0.1)$. However, neither milk yield nor fat and protein contents were associated with C-LA $(P=0.37, P=0.89$, and $P=0.95$, respectively; data not shown). Feeding system did not affect the risk to resume luteal activity $(P=0.80)$.

Genetic and Feeding System Affect Ovarian Cycle Length. The length of the first cycle was not affected by breed or genetic group in this study (Figure 2; Table 4). Subsequent cycles were longer for Holstein than for Normande cows $(+1.7 \mathrm{~d}, P<0.001)$ because of a combination of longer luteal phase $(+0.9 \mathrm{~d}, P<$ $0.05)$ and longer interluteal phase intervals $(+0.6 \mathrm{~d}, P$ $<0.05$ ). Cows in the low feeding system had shorter first luteal phase $(-2.6 \mathrm{~d}, P<0.05)$ and shorter first cycles $(-2 \mathrm{~d}, P<0.05)$ than cows in the high feeding system.

Occurrence of PLP Was Not Affected by Genetics or Feeding System. The proportion of primiparous cows experiencing PLP (18\%) was not affected by breed $(P=0.30)$, genetic group $(P=0.75$ and $P=0.21$ for Holstein and Normande, respectively), or feeding system $(P=0.29)$.

\section{DISCUSSION}

Our results confirmed that primiparous cows have delayed C-LA, consistent with the literature (Opsomer 
GENETICS OF CYCLICITY OF PRIMIPAROUS COWS

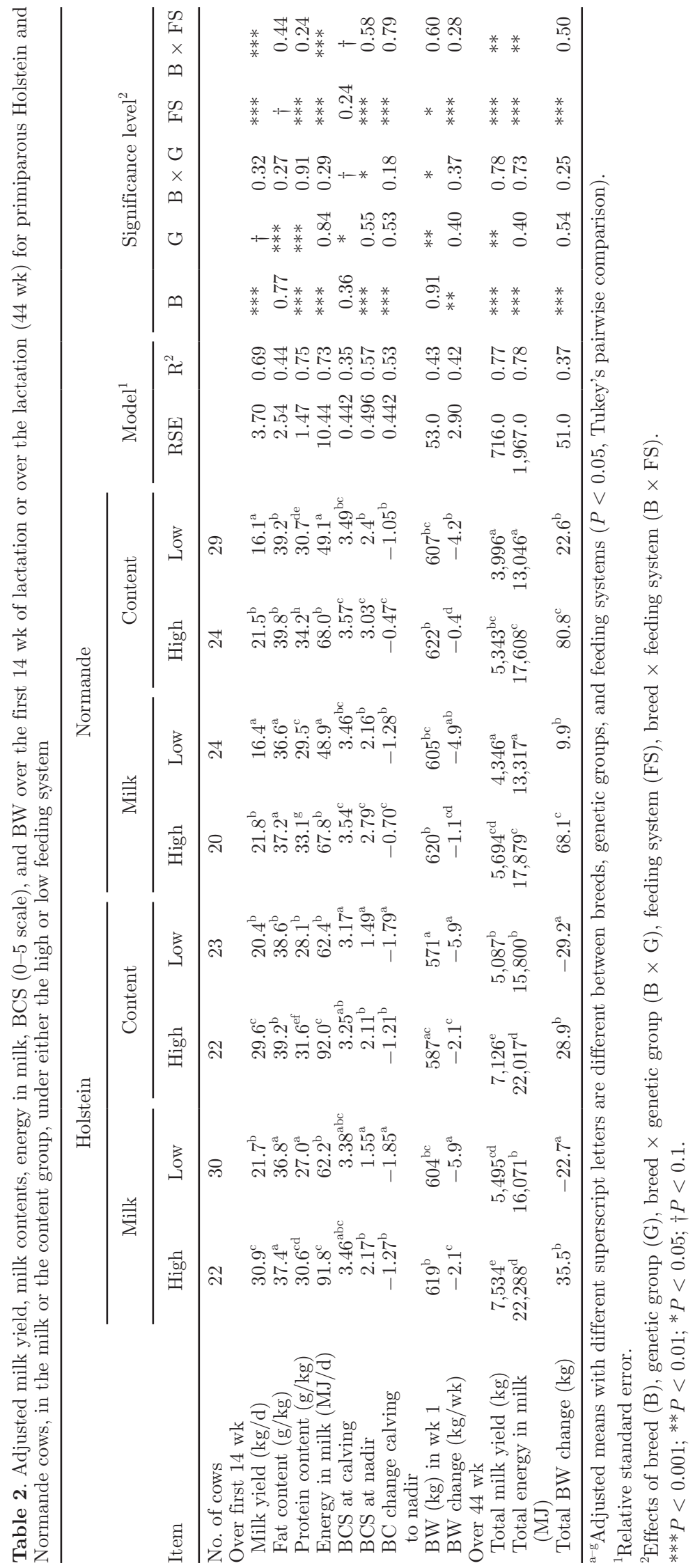


Observations

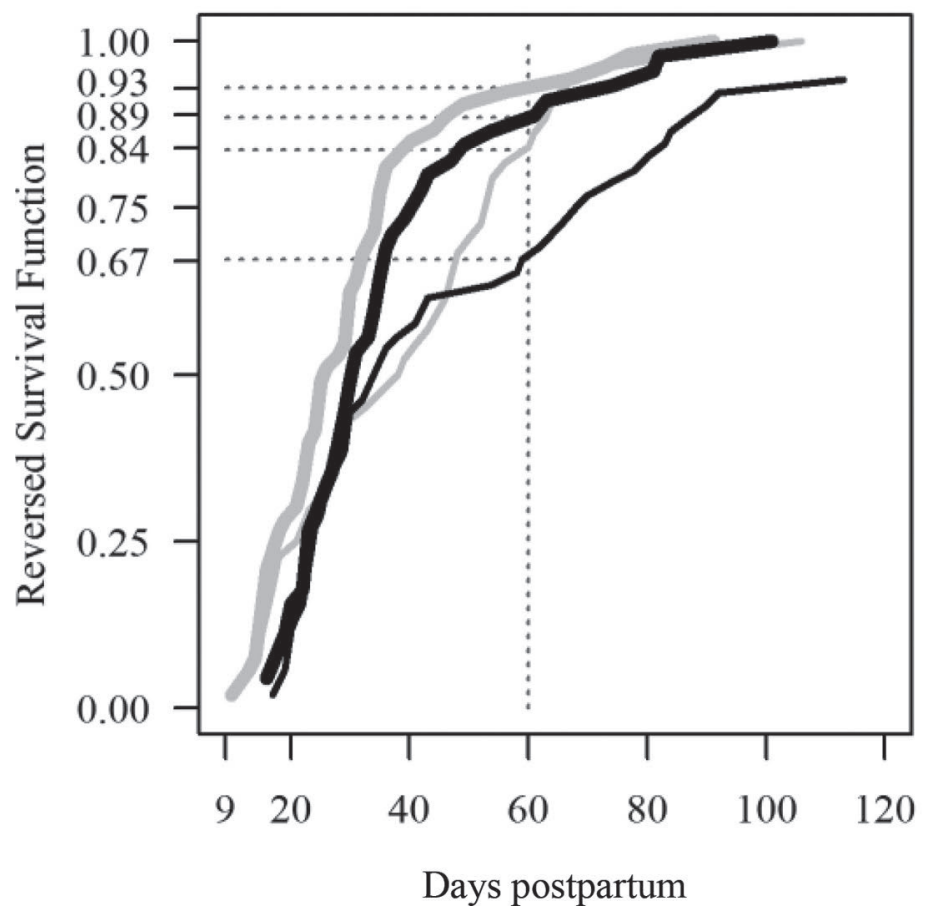

Model predictions

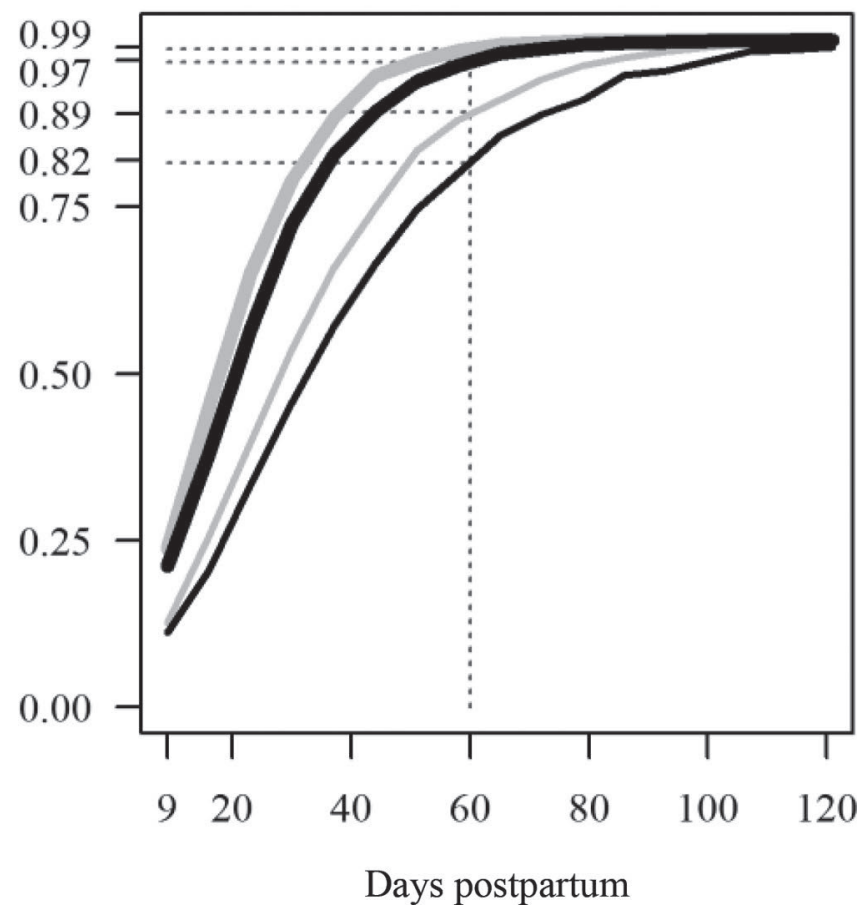

Figure 1. Observed reversed survival function (cumulative proportions) of cows that resumed luteal activity, over the first $120 \mathrm{~d}$ postpartum of Holstein $(\mathrm{n}=97$, black) or Normande $(\mathrm{n}=97$, gray) cows, belonging either to the milk genetic group $(\mathrm{n}=96$, thin lines $)$ or to the content genetic group ( $\mathrm{n}=98$, thick lines).

et al., 1998; Taylor et al., 2003; Disenhaus et al., 2009). In this study, we used survival analyses to study time to C-LA. Survival analyses were developed in biomedical and epidemiological statistics and proved suited for small experimental data sets. They allow an assessment of the effect of experimental factors and covariates (Gröhn et al., 1998; Mandonnet et al., 2003). Among survival analyses, we used a proportional hazards model. Simple proportional hazards models have 2 major potential limits: it is not always correct to assume hazards

Table 3. Estimated effect sizes $(\hat{\beta})$, associated hazard $\operatorname{ratios}[H R=\exp (\hat{\beta})]$, and $95 \% \mathrm{CI}$ of factors influencing time to commencement of luteal activity (C-LA; $\mathrm{n}=194$, of which 2 are censored)

\begin{tabular}{|c|c|c|c|c|c|c|}
\hline Risk factor & Category (\%) & Estimate & $\mathrm{SE}$ & $\mathrm{HR}$ & $95 \%$ CI & $P$-value \\
\hline Calving problems & & & & & & $* *$ \\
\hline No & 74 & 0.54 & 0.183 & 1.7 & $1.2-2.5$ & \\
\hline Yes & 26 & 0 & - & 1.0 & - & \\
\hline Genetic group & & & & & & $* * *$ \\
\hline Milk & 49 & 0 & - & 1.0 & - & \\
\hline Content & 51 & 0.70 & 0.216 & 2.0 & $1.3-3.1$ & \\
\hline Breed $\times$ genetic group & & & & & & 0.62 \\
\hline Holstein $\times$ Milk & 26 & -0.15 & 0.306 & 0.9 & - & \\
\hline Holstein $\times$ Content & 23 & 0 & - & 1.0 & - & \\
\hline Normande $\times$ Milk & 23 & 0.15 & - & 1.2 & - & \\
\hline Normande $\times$ Content & $\begin{array}{c}28 \\
(\text { Mean } \\
\pm \text { SD })\end{array}$ & 0 & - & 1.0 & - & \\
\hline EBV (milk yield) ${ }^{1}$ & $0 \pm 402$ & -0.0005 & 0.00026 & - & - & $*$ \\
\hline $\mathrm{BW}$ in wk $1^{2}$ & $0 \pm 55$ & 0.003 & 0.0015 & - & - & $\dagger$ \\
\hline BW change & $-2 \pm 15$ & 0.01 & 0.005 & - & - & $\dagger$ \\
\hline
\end{tabular}

${ }^{1}$ EBV has a null mean because it was centered within breed and genetic group.

${ }^{2} \mathrm{BW}$ has a null mean because it was centered within breed, genetic group, and calving age.

*** $P<0.001 ;{ }^{* *} P<0.01 ; * P<0.05 ; \dagger P<0.1$. 
Holstein 1st ov. $(n=49)$

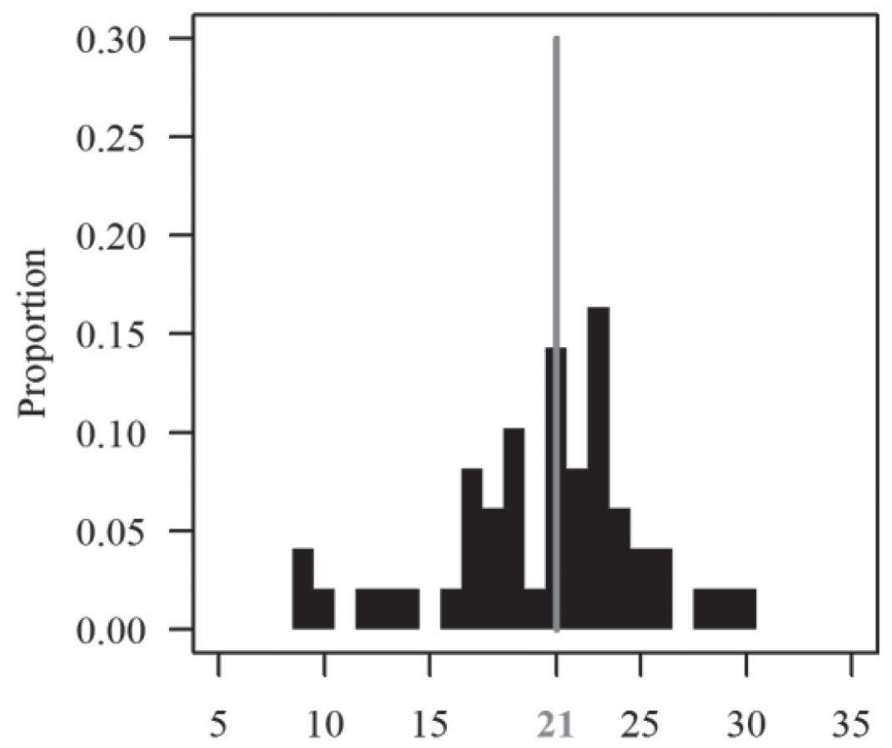

Normande 1st ov. $(\mathrm{n}=61)$

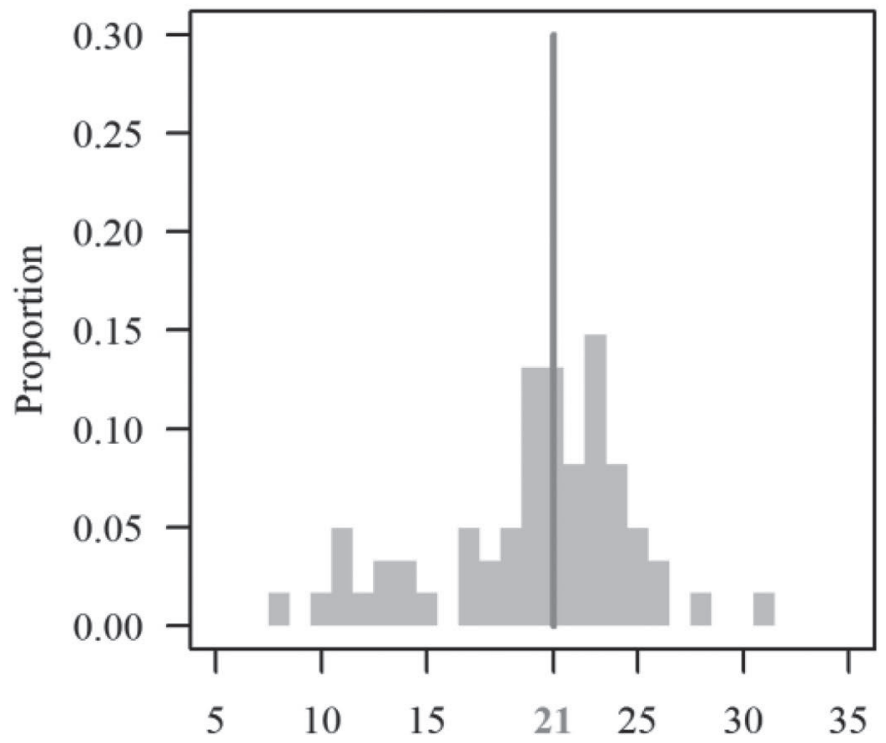

Holstein 2nd-4th ov. $(n=85)$

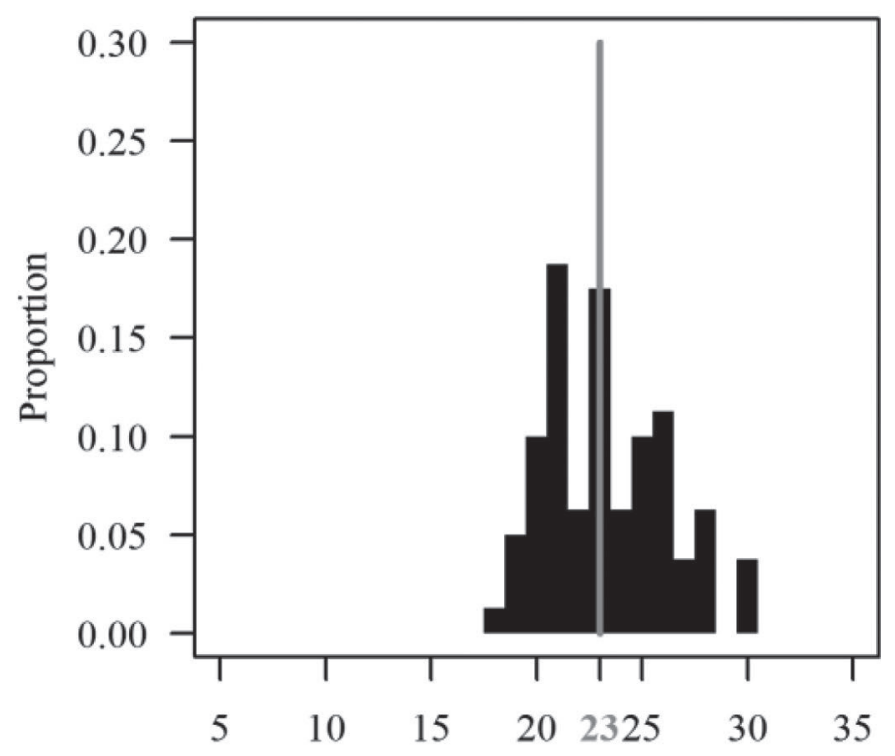

Normande 2nd-4th ov. ( $n=124)$

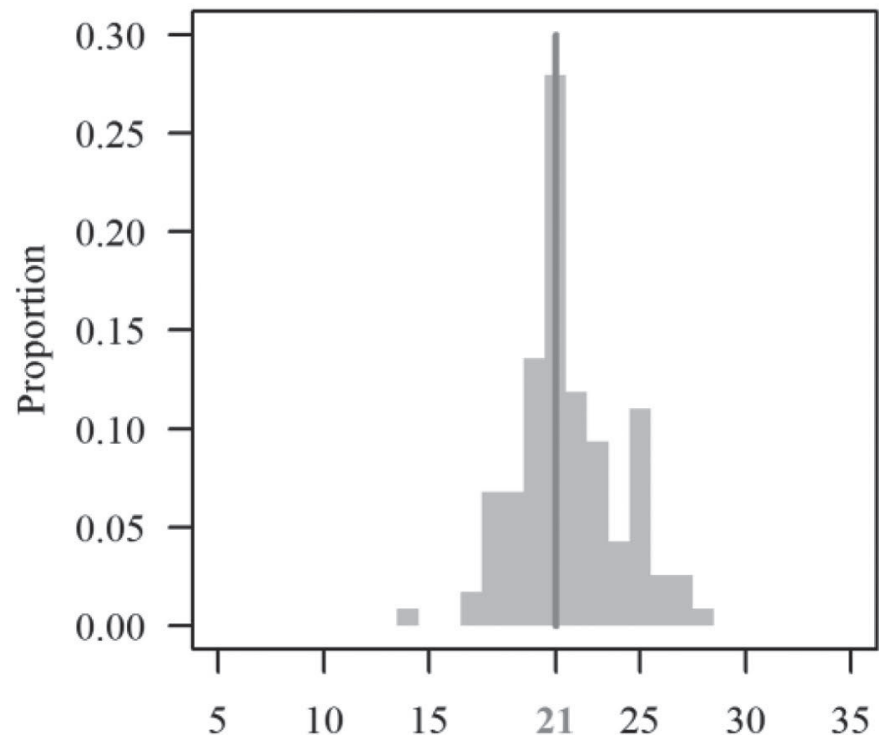

Figure 2. Distributions of cycle length (interovulatory interval, IOI) of the first ovulation (ov.) or for second to fourth ovulations not associated with a service, a prolonged luteal phase, or a delayed ovulation for Holstein and Normande primiparous cows.

to be proportional among individuals and across time. We identified a need for stratification in this study, considering each breed as a sub-population. Hazards were always proportional within breed but not across breeds. In addition, we had time-dependent covariates (e.g., BW) and we used an extension of the PHM that considers covariate changes over time. With these, we made the most complete use of the information avail- able to study risk factors associated with C-LA and were able to quantify their effects.

As expected, Holstein cows had later C-LA than Normande cows. In other studies, C-LA occurred later for breeds selected for milk yield compared with dualpurpose breeds (Petersson et al., 2006; Disenhaus et al., 2009; Piccand et al., 2013). Commencement of luteal activity was mainly affected by genetic characteristics, 


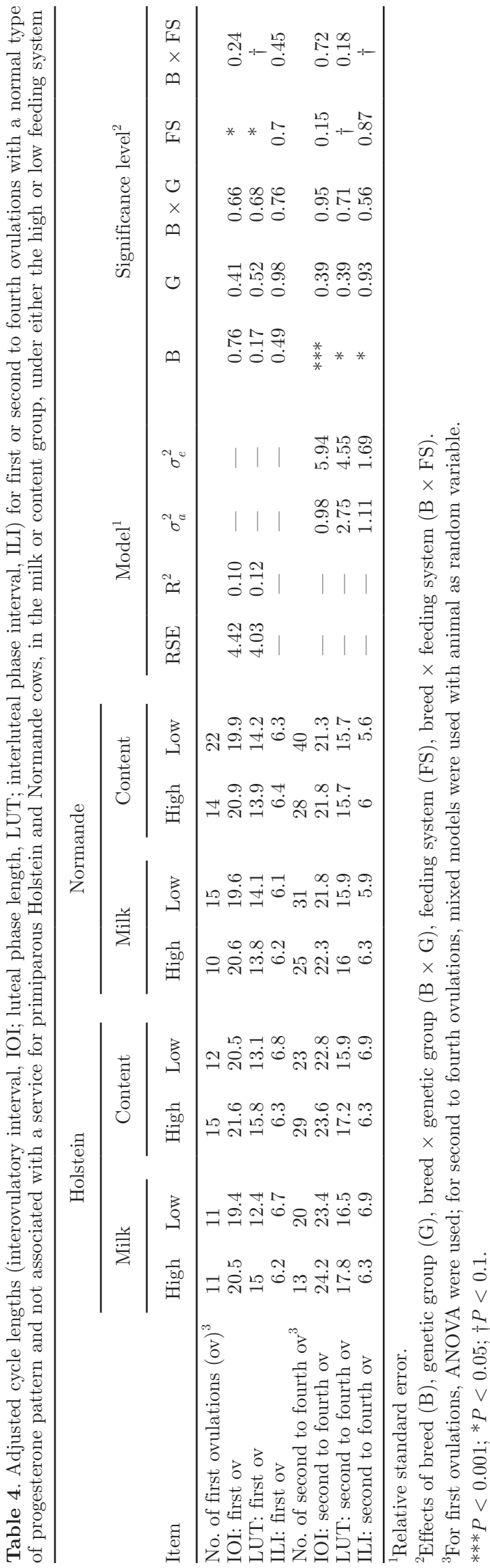

which is consistent with the fact that C-LA has a moderate heritability, ranging from 0.13 to 0.30 (Veerkamp et al., 2000; Royal et al., 2002b; Petersson et al., 2007). As expected, cows with the highest EBV for milk yield had later C-LA (Pollott and Coffey, 2008; Windig et al., 2008; Garmo et al., 2009). In addition, exporting milk energy through higher fat and protein contents was associated with earlier C-LA. To our knowledge, the relationship between the way of exporting energy in milk and reproduction performance of primiparous cows has not previously been investigated. These findings reinforce the genetic and phenotypic relationships between milk yield and C-LA. Further investigations are needed to describe the genetic and biological differences between cows exporting energy in milk through higher yield compared with through higher fat and protein contents. We could hypothesize that selecting on milk fat and protein yield is desirable for animals' robustness and durability of dairy systems.

In this experiment, cows were fed ad libitum even though the 2 feeding systems differed in nutrient intake. The low feeding system was very restrictive, causing insufficient energy intake, associated with a large BCS loss and a limited milk yield. In addition, this contrast between the high and low feeding systems partly disentangled the concomitant effects of milk yield and body reserve mobilization. Cows in the high feeding system produced greater milk yield and lost less BCS than did those in the low feeding system. We found no effect of feeding system on cyclicity, even with the contrast created by these 2 feeding systems. This is consistent with most studies, in which authors also found a relationship between cyclicity and intake (Burke and Roche, 2007), energy balance (Chagas et al., 2008; Pollott and Coffey, 2008), or protein balance (Bruckental et al., 2000; Law et al., 2009). As expected, we found that later C-LA was associated with greater BW at calving and greater BW loss. However, we found no association with milk yield (Friggens et al., 2010).

In this study, cycle length, luteal phase length, and interluteal phase interval of the first cycle were not affected by genetics and feeding system, which is consistent with the literature (Pollott and Coffey, 2008; Windig et al., 2008; Gilmore et al., 2011). However, second to fourth ovulation cycles were longer in Holstein cows than in Normande cows. Previous studies also reported that Holstein cows have longer ovarian cycles than other breeds (Disenhaus et al., 2009; Piccand et al., 2013). Feeding system did not affect the proportion of cows with a PLP type of P4 profiles. However, PLP are known to be associated with milk yield (Royal et al., 2002a; Kafi et al., 2012) and to BCS at calving and loss (Friggens et al., 2010). Further investigations are 
needed to clarify the relationship between the occurrence of PLP and milk yield or BCS.

To conclude, this study on primiparous dairy cows confirmed that C-LA was strongly related to genetic merit for milk yield. Our results suggest it could be desirable to select cows for production traits through higher fat and protein contents rather than higher milk yield to reach durable systems. Cows with higher fat and protein contents produce enriched milk, which can be cost effective for the dairy industry, and they are more likely to reproduce on time, which is desirable for their robustness to farming system constraints.

\section{ACKNOWLEDGMENTS}

This study is part of the European Project Pluridisciplinary study for a RObust and sustainabLe Improvement of Fertility In Cows (PROLIFIC). The study was partly funded by PROLIFIC and the Britany Region, France. We thank the staff of the experimental farm of Le Pin-au-Haras for their help in managing the herd, taking care of the animals, and collecting the samples. We are also grateful to the laboratory staff of INRA and Agrocampus Ouest for analyzing all the samples collected.

\section{REFERENCES}

Bazin, S., P. Augeard, M. Carteau, H. Champion, Y. Chilliard, G. Cuylle, C. Disenhaus, G. Durand, R. Espinasse, A. Gascoin, M. Godineau, D. Jouanne, O. Ollivier, and B. Remond. 1984. Grille de notation de l'état d'engraissement des vaches pie-noires. RNED Bovin, Paris, France.

Bruckental, I., M. Holtzman, M. Kaim, Y. Aharoni, S. Zamwell, H. Voet, and A. Arieli. 2000. Effect of amount of undegradable crude protein in the diets of high-yielding dairy cows on energy balance and reproduction. Livest. Prod. Sci. 63:131-140.

Burke, C. R., and J. R. Roche. 2007. Effects of pasture feeding during the periparturient period on postpartum anovulation in grazed dairy cows. J. Dairy Sci. 90:4304-4312. http://dx.doi.org/10.3168/ jds.2006-788

Canfield, R. W.. C. J. Sniffen, and W. R. Butler. 1990. Effects of excess degradable protein on postpartum reproduction and energy balance in dairy cattle. J. Dairy Sci. 73:2342-2349. http://dx.doi. org/10.3168/jds.S0022-0302(90)78916-3.

Chagas, L. M., P. J. S. Gore, G. Graham, K. A. Macdonald, and D. Blache. 2008. Effect of restricted feeding and monopropylene glycol postpartum on metabolic hormones and postpartum anestrus in grazing dairy heifers. J. Dairy Sci. 91:1822-1833. http://dx.doi. org/10.3168/jds.2007-0339.

Coffey, M. P., J. Hickey, and S. Brotherstone. 2006. Genetic aspects of growth of Holstein-Friesian dairy cows from birth to maturity. J. Dairy Sci. 89:322-329. http://dx.doi.org/10.3168/jds.S00220302(06)72097-5.

Cox, D. R. 2007. Regression models and life-tables. J. R. Stat. Soc., B 34:187-220. http://dx.doi.org/10.2307/2985181.

Cutullic, E., L. Delaby, Y. Gallard, and C. Disenhaus. 2011. Dairy cows' reproductive response to feeding level differs according to the reproductive stage and the breed. Animal 5:731-740. http:// dx.doi.org/10.1017/S1751731110002235.

Cutullic, E., L. Delaby, Y. Gallard, and C. Disenhaus. 2012. Towards a better understanding of the respective effects of milk yield and body condition dynamics on reproduction in Holstein dairy cows. Animal 6:476-487. http://dx.doi.org/10.1017/S175173111100173X.

Darwash, A. O., G. E. Lamming, and J. A. Wooliams. 1997. The phenotypic association between the interval to post-partum ovulation and traditional measures of fertility in dairy cattle. Anim. Sci. 65:9-16. http://dx.doi.org/10.1017/S1357729800016234.

Disenhaus, C., E. Cutullic, F. Blanc, and J. Agabriel. 2009. Breed comparison of postpartum ovarian activity in cows. J. Dairy Sci. 92(E. Suppl. 1):498. (Abstr.)

Faverdin, P., R. Delagarde, L. Delaby, and F. Meschy. 2007. Alimentation des vaches laitières. Pages 23-55 in Alimentation des Bovins, Ovins et Caprins: Besoins des Animaux-Valeurs des Aliments. INRA, Versailles, France.

Friggens, N. C., C. Disenhaus, and H. V. Petit. 2010. Nutritional subfertility in the dairy cow: towards improved reproductive management through a better biological understanding. Animal 4:11971213. http://dx.doi.org/10.1017/S1751731109991601.

Garmo, R. T., E. Ropstad, Ø. Havrevoll, E. Thuen, H. Steinshamn, A. Waldmann, and O. Reksen. 2009. Commencement of luteal activity in three different selection lines for milk yield and fertility in Norwegian Red cows. J. Dairy Sci. 92:2159-2165. http://dx.doi. org/10.3168/jds.2008-1295.

Gautam, G., T. Nakao, K. Yamada, and C. Yoshida. 2010. Defining delayed resumption of ovarian activity postpartum and its impact on subsequent reproductive performance in Holstein cows. Theriogenology 73:180-189. http://dx.doi.org/10.1016/j. theriogenology.2009.08.011.

Gilmore, H. S., F. J. Young, D. C. Patterson, A. R. G. Wylie, R. A. Law, D. J. Kilpatrick, C. T. Elliott, and C. S. Mayne. 2011. An evaluation of the effect of altering nutrition and nutritional strategies in early lactation on reproductive performance and estrous behavior of high-yielding Holstein-Friesian dairy cows. J. Dairy Sci. 94:3510-3526. http://dx.doi.org/10.3168/jds.2010-3547.

Gröhn, Y. T., S. Eicker, V. Ducrocq, and J. Hertl. 1998. Effect of diseases on the culling of Holstein dairy cows in New York State. J. Dairy Sci. 81:966-978.

Horan, B., J. F. Mee, M. Rath, P. O'Connor, and P. Dillon. 2004. The effect of strain of Holstein-Friesian cow and feeding system on reproductive performance in seasonal-calving milk production systems. Anim. Sci. 79:453-467.

Kafi, M., A. Mirzaei, A. Tamadon, and M. Saeb. 2012. Factors affecting the occurrence of postpartum prolonged luteal activity in clinically healthy high-producing dairy cows. Theriogenology 77:421429. http://dx.doi.org/10.1016/j.theriogenology.2011.08.016.

Kalbfleisch, J., and R. Prentice. 2002. The Statistical Analysis of Failure Time Data. 2nd ed. John Wiley and Sons, New York, NY.

Kaplan, E. L., and P. Meier. 1958. Nonparametric estimation from incomplete observations. J. Am. Stat. Assoc. 53:457-481. http:// dx.doi.org/10.2307/2281868.

Law, R. A., F. J. Young, D. C. Patterson, D. J. Kilpatrick, A. R. Wylie, and C. S. Mayne. 2009. Effect of dietary protein content on the fertility of dairy cows during early and mid lactation. J. Dairy Sci. 92:2737-2746. http://dx.doi.org/10.3168/jds.2008-1420.

Le Cozler, Y., V. Lollivier, P. Lacasse, and C. Disenhaus. 2008. Rearing strategy and optimizing first-calving targets in dairy heifers: A review. Animal 2:1393-1404. http://dx.doi.org/10.1017/ S1751731108002498.

Mandonnet, N., V. Ducrocq, R. Arquet, and G. Aumont. 2003. Mortality of Creole kids during infection with gastrointestinal strongyles: A survival analysis. J. Anim. Sci. 81:2401-2408.

Mészáros, G., J. Sölkner, and V. Ducrocq. 2013. The Survival Kit: software to analyze survival data including possibly correlated random effects. Comput. Methods Programs Biomed. 110:503-510. http://dx.doi.org/10.1016/j.cmpb.2013.01.010.

Opsomer, G., M. Coryn, H. Deluyker, and A. de Kruif. 1998. An analysis of ovarian dysfunction in high yielding dairy cows after calving based on progesterone profiles. Reprod. Domest. Anim. 33:193-204.

Petersson, K.-J., B. Berglund, E. Strandberg, H. Gustafsson, A. P. F. Flint, J. A. Woolliams, and M. D. Royal. 2007. Genetic analysis of postpartum measures of luteal activity in dairy cows. J. Dairy Sci. 
90:427-434. http://dx.doi.org/10.3168/jds.S0022-0302(07)726449.

Petersson, K.-J., H. Gustafsson, E. Strandberg, and B. Berglund. 2006. Atypical progesterone profiles and fertility in Swedish dairy cows. J. Dairy Sci. 89:2529-2538. http://dx.doi.org/10.3168/jds. S0022-0302(06)72328-1.

Piccand, V., E. Cutullic, S. Meier, F. Schori, P. L. Kunz, J. R. Roche, and P. Thomet. 2013. Production and reproduction of Fleckvieh, Brown Swiss, and 2 strains of Holstein-Friesian cows in a pasturebased, seasonal-calving dairy system. J. Dairy Sci. 96:5352-5363. http://dx.doi.org/10.3168/jds.2012-6444.

Pollott, G. E., and M. P. Coffey. 2008. The effect of genetic merit and production system on dairy cow fertility, measured using progesterone profiles and on-farm recording. J. Dairy Sci. 91:3649-3660. http://dx.doi.org/10.3168/jds.2007-0913.

R Core Team. 2014. R: A Language and Environment for Statistical Computing. R Development Core Team, Vienna, Austria.

Royal, M. D., J. Pryce, J. Woolliams, and A. Flint. 2002a. The genetic relationship between commencement of luteal activity and calving interval, body condition score, production, and linear type traits in Holstein-Friesian. J. Dairy Sci. 85:3071-3080.
Royal, M. D., A. P. F. Flint, and J. A. Woolliams. 2002b. Genetic and phenotypic relationships among endocrine and traditional fertility traits and production traits in Holstein-Friesian dairy cows. J. Dairy Sci. 85:958-967. http://dx.doi.org/10.3168/jds.S00220302(02)74155-6.

Taylor, V. J., D. E. Beever, M. J. Bryant, and D. C. Wathes. 2003 Metabolic profiles and progesterone cycles in first lactation dairy cows. Theriogenology 59:1661-1677. http://dx.doi.org/10.1016/ S0093-691X(02)01225-6.

Veerkamp, R. F., J. K. Oldenbroek, H. J. van der Gaast, and J. H. J. van der Werf. 2000. Genetic correlation between days until start of luteal activity and milk yield, energy balance, and live weights. J. Dairy Sci. 83:577-583. http://dx.doi.org/10.3168/jds.S00220302(00)74917-4.

Windig, J. J., B. Beerda, and R. Veerkamp. 2008. Relationship between milk progesterone profiles and genetic merit for milk production, milking frequency, and feeding regimen in dairy cattle. J. Dairy Sci. 91:2874-2884. http://dx.doi.org/10.3168/jds.2007-0111. 